\title{
SISTEM PENUNJANG KEPUTUSAN \\ PEMILIHAN MERK LAPTOP TERBAIK MENGGUNAKAN METODE ANALITICAL HIERARCHY PROCESS (AHP)
}

\author{
Jihan Namira Adzani Ramadina1, Eka Rini Yulia ${ }^{2 *}$ \\ ${ }^{12}$ Fakultas Teknologi Informasi, Program Studi Sistem Informasi, Universitas Nusa Mandiri, Jakarta, Indonesia \\ Email: ${ }^{1}$ jhnnmr06@gmail.com, ${ }^{2 *}$ eka.erl@nusamandiri.ac.id \\ (* : coressponding author)
}

\begin{abstract}
Abstrak-Komputer salah satunya laptop telah melewati berbagai proses lebih cepat saat ini. Baik itu dari desain maupun hardware, dan software. Dengan adanya perkembangan zaman, kemampuan laptop akan mempengaruhi harga laptop. Semakin tinggi spesifikasi, semakin tinggi pula harganya dan tentunya sudah memiliki kegunaan yang terbilang diatas. Oleh karena itu, banyak mahasiswa atau mahasiswi dan orang-orang bingung untuk menentukan pilihan merk laptop terbaiknya. Sistem penunjang keputusan adalah salah satu cara atau solusi dari suatu perbuatan untuk memecahkan suatu masalah. Pada akhirnya, dari pemecahan masalah ini dapat diselesaikan dengan baik, efisien dan efektif menggunakan metode AHP. Dari hasil perhitungan, laptop yang sangat popular dan diminati merupakan laptop acer dengan prosentase $40 \%$. Kemudian populer kedua merupakan Laptop HP dengan prosentase 35\%. Populer ketiga, Laptop Dell prosentase 14\%. Posisi terakhir adalah dari segi Ukuran Layar, mendaptkan prosentase $11 \%$. Berdasarkan hasil penelitian serta prosentase yang didapat, bisa disimpulkan bahwa laptop acer paling diminati dari berbagai merk laptop.
\end{abstract}

Kata Kunci: Pemilihan Merk Laptop, AHP

\begin{abstract}
Computers, one of which is a laptop, have gone through various processes faster today. Both in terms of design, hardware, and software. With the development of the times, the ability of the laptop will affect the price of the laptop. The higher the specifications, the higher the price and of course it already has the uses listed above. Therefore, many college students and people are confused about choosing the best laptop brand. The decision support system is one way or solution of an action to solve a problem. In the end, from solving this problem can be solved properly, efficiently, and effectively using the AHP method. From the results of calculations, the laptop that is very popular and in-demand is an Acer laptop with a percentage of $40 \%$. Then the second popular is HP Laptops with a percentage of 35\%. The third most popular, Dell Laptops, the percentage is 14\%. The last position is in terms of Screen Size, getting a percentage of $11 \%$. Based on the results of the study and the percentage obtained, it can be concluded that Acer laptops are the most in-demand from various laptop brands.
\end{abstract}

Keywords: Desicion Support system Of Laptop brand, AHP (Analytical Hierarchy Process)

\section{PENDAHULUAN}

\subsection{Latar Belakang Penelitian}

Komputer salah satunya laptop telah melewati berbagai proses lebih cepat saat ini. Baik itu dari desain maupun hardware, dan software. Dengan adanya perkembangan zaman, kemampuan laptop akan mempengaruhi harga laptop. Semakin tinggi spesifikasinya, semakin tinggi juga harganya dan tentunya sudah mempunyai kegunaan yang terbilang diatas cukup. Banyaknya merk laptop saat ini, sangat memicu pertumbuhan saling ingin jadi yang nomor 1 dalam teknologi untuk memenuhi kebutuhan manusia.

Apalagi khususnya bagi programmer, gamming, tentunya pasti sangat ingin memiliki laptop yang spesifikasinya tinggi. Berdasarkan dari banyaknya pilihan laptop yang dijual dipasaran sekarang, dimulai dari merk, desain, spesifikasi serta fungsi dari macam-macam laptop yang membuat pengguna akan sangat bingung dalam memilih keputusan merk laptop terbaiknya.

"Pelanggan memiliki pemikiran yang berbeda tentang kualitas dan belum tentu dapat diterima. Kualitas buruk memiliki nilai harga yang lebih rendah dari ambang batasnya” [1]. Karena tidak dipungkiri, manusia bukanlah mahkluk hidup yang mudah untuk menentukan pilihan. Terkadang melihat spesifikasi yang bagus dan design yang friendly pasti ada kebingungan untuk membeli. Hingga lupa sebaiknya membeli tergantung kebutuhan saja.

"Pilihan paling tepat adalah membeli sesuai dengan kebutuhan" [2]Oleh sebab itu, peneliti akan mengutarakan tentang sistem penunjang keputusan merk laptop terbaik yang diharapkan dapat membantu dalam 
memenuhi kebutuhan para pengguna. Hasil dari penelitian ini, memberikan keputusan dan alternatif dalam pemecahan permasalahan yang terbaik.

Hal ini dikarenakan metode AHP mempunyai kelebihan dari sisi metode pengambil keputusan atributatribut kualitatif dan kuantitatif. Pengertian inkosistensi mengasumsikan kebenaran standart serta opsi sampai batas yang telah ditentukan dalam pengambil keputusan.

\subsection{Pengertian Keputusan}

"Pengambilan keputusan adalah bentuk suatu usaha yang bertujuan untuk menciptakan kejadian-kejadian di masa depan" [3]. "Pertimbangan yang berhasil tergantung kepada keunggulan pada pertimbangan, penerimaan bawahan, dan ketelitian" [4].

\subsection{Pengertian Pengambilan Keputusan}

"Pengambilan keputusan adalah proses terjadinya evaluasi dari berbagai alternatif yang berhubungan. Yang mempunyai tujuan tersendiri atau terorganisasi” [5].

\subsection{Sistem Penunjang Keputusan}

Tahun 1970, Michael S.Scott Morton pertama kali mengumumkan Sistem Penunjang keputusan dengan istilah Management Decision System. Sistem Penunjang Keputusan tidak mengoptimasikan penutipan keputusan, tapi mewariskan interaktif perangkat pengutipan, dalam menjalankan bermacam analis menggunakan model yang ada. "Sistem Penunjang Keputusan adalah sistem informasi yang menyajikan informasi, permodelan, dan kecurangan data” [6].

\subsection{Analitical Hierarchy Process}

"Hirarki didefinisikan sebagai representasi dari masalah yang lengkap,. Dalam struktur multi-level, level pertama adalah tujuan, dan kemudian level faktor, standar, sub-kondisi, dll” [7].

Dalam menyelesaikan masalah menggunakan metode AHP, prinsip yang wajib dipahami ialah:

a. Dekomposisi

Sistem yang rumit dapat dimengerti dengan memecahkan menjadi anggota-anggota terseleksi atau berkurang. Oleh karena itu, dapat dengan mudah dimengerti. Kemudian disusun secara hirarki, seperti pada gambar dibawah ini.

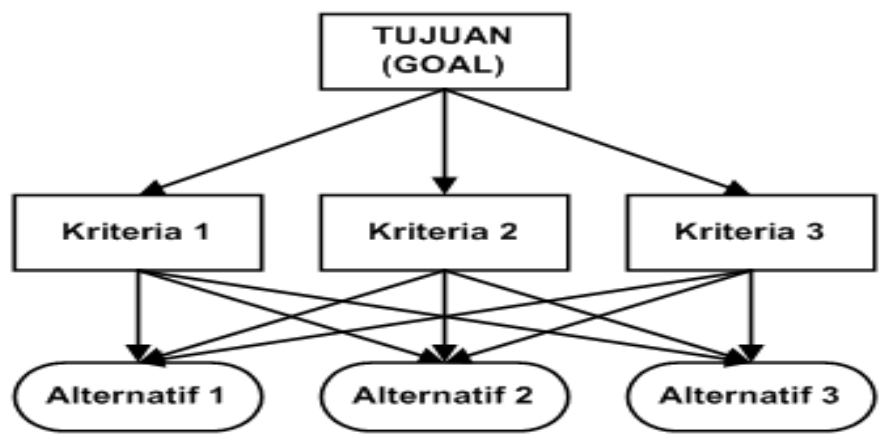

Gambar 1. Struktur Hirarki

b. Penilaian Komparatif

Kriteria serta alternatif dapat dilakukan melalui perbandingan berpasangan.

c. Sintesis Prioritas

Prioritaskan anggota pikirkan standar sebagai bobot/kontribusi. Anggota-anggota ini untuk mencapai tujuan pengambilan yang diputuskan. Analisis prioritas elemen eksekutif AHP metode perbandingan berpasangan antara keduanya elemen untuk menutupi semua elemen yang ada. Prioritas didasarkan pada sudut pandang segmen ahli yang tertarik pengambilan keputusan langsung(diskusi) dan tidak langsung (survei kuesioner).

d. Konsistensi Logis

Konsistensi mempunyai dua arti. Pertama, merupakan objek yang dapat dikelompokkan dalam persamaan kesatuan dan relevansi. Kedua, hubungan antar objek yang menjadi perhatian menurut pada standart yang logis. 
available online at http://jom.fti.budiluhur.ac.id/index.php/IDEALIS/index

\subsection{AHP Sebagai Teori Pengambilan Keputusan}

Tahap pertama yaitu menyusun perbandingan berdasarkan persamaan, yaitu mengkonversikan kedalam matriks. Kemudian menghitung bobot berdasarkan elemen, dalam perhitungan ini dibutuhkan tabel Random Index (RI) seperti dalam Tabel 1:

Tabel 1. Nilai Index Acak (Random Index)

\begin{tabular}{cccccccccc}
\hline $\mathrm{N}$ & 2 & 3 & 4 & 5 & 6 & 7 & 8 & 9 & 10 \\
\hline $\mathrm{Ri}$ & 0 & 0.58 & 0.9 & 1.12 & 1.24 & 1.32 & 1.41 & 1.45 & 1.49 \\
\hline \multicolumn{2}{l}{ Sumber:[9] }
\end{tabular}

Dalam proses pengambilan keputusan, dimana harus ada keputusan yang konsisten, contohnya $C R \leq 0,1$ (Nilai Rasio Konsisten $\leq 0,1$ ) sehingga rasio inkonsitensi data akan menghasilkan data yang dianggap baik. Terbukti dari rumus (1), indek konsistensi dan matriks berordo ๆ berikut [10]:

$$
\begin{aligned}
& C I=\text { indeks konsistensi } \\
& \text { Rumus } C I=\left(\lambda_{\max }-n\right) /(n-1) \\
& R I=\text { indeks random } \\
& \text { Rumus } C R=C I / R I
\end{aligned}
$$

\section{METODE PENELITIAN}

Peneliti menggunakan beberapa metode untuk melakukan penelitian, sebagaimana untuk mengarahkan bervariasi dari masalah yang ada. Antara lain :

a Observasi

Peneliti mencari dan mengumpulkan data-data yang dibutuhkan secara mengamati langsung mengenai Mahasiswa dan orang awam yang masih bingung untuk memilih laptop yang akan dibeli.

b Wawancara Peneliti melakukan wawancara dengan cara tanya jawab secara online terhadap Bapak Warinto sebagai orang awam dan Amin sebagai Mahasiswi.

c Studi Pustaka

Untuk menambah informasi, peneliti membutuhkan data-data tambahan untuk melengkapi penyusunan laporan penelitian ini melalui referensi jurnal.

\subsection{Hipotesa}

Hipotesa sangat berpengaruh pada sistem penunjang keputusan pemilihan merk Laptop sehingga peneliti membuat kriteria dan alternatif dalam pemilihan merk Laptop.

H0 : Tidak adanya pengaruh nilai plus spesifikasi dalam menentukan merk Laptop.

H1 : Adanya pengaruh nilai plus spesifikasi dalam menentukan merk Laptop.

\subsection{Tahapan Penelitian}

Proses dari metode penelitian dapat dijelaskan dibawah ini:

a. Perumusan Masalah

Proses penentuan masalah ini, memastikan bahwa masalah yang ada saat menentukan masalah memenuhi batasan ruang lingkup.

b. Perumusan Tujuan dari Masalah

Untuk memastikan bahwa tujuan yang ingin dicapai dengan merumuskan masalah yang muncul dalam penelitian ilmiah ini, maka tujuan dari penelitian ini adalah menggunakan metode AHP dalam pemilihan merk Laptop.

c. Identifikasi Masalah

Identifikasi Masalah dapat disimpulkan dengan adanya dan diberlakukan yang mempunyai maksud untuk cari tahu penyebab masalahnya dan mencari inti dari masalah yang ada dengan Pemilihan Merk Laptop pada Mahasiswa/i dan orang awam.

d. Studi Pustaka

Sumber ini bermula dari buku dan jurnal.

Standar dan bobot penelitian pemilihan merk laptop:

1. Kriteria Pemilihan Merk Laptop 
Standar yang dimanfaatkan pada proses pemilihan merk laptop pada Mahasiswa dan orang dibawah ini, sebagai berikut:
a. Harga
b. Memori
c. HardDisk
d. Ukuran Layar

2. Nilai Standar

Memberi nilai-nilai kriteria yang telah ditentukan berdasarkan kuesioner yang didapat Mahasiswa dan Orang awam.

e. Pengumpulan Data Primer

Mengumpulkan informasi data primer ini, data dapat diambil berdasarkan data pada kuesioner yang telah diisi oleh dari target/responden. Memberikan bobot penelitian dari masing-masing informasi responden sesuai kriteria yang sudah ditentukan/dibuat.

f. Pengolahan informasi bisa diberikan dari pemberian Kode Variabel.

Tindakan ini memerlukan adanya metode AHP.

g. Deskripsi Hasil Penelitian

Menelaah hasil penyusunan data-data yang didapat berdasarkan teori-teori dalam menggunakan metode AHP sehingga mendapatkan hasil yang terbaik dari penelitian.

\section{HASIL DAN PEMBAHASAN}

\subsection{Analisa Data}

Kuesioner yang sudah disebarkan kepada 30 responden, para orang awam dan mahasiswi dilingkungan sekitar. Penyebaran kuesioner dilakukan secara online terhadap responden. Penyebaran kuesioner dimulai pada bulan Mei 2021. Jumlah kuesioner yang disebarkan sebanyak 30 kuesioner. Untuk mempermudah pengisian dan pengolahan data, maka dibuatlah kriteria dan alternatif pada pemilihan Merk Laptop. Adapun kriteria dan alternatif yang dimanfaatkan untuk penelitian ilmiah ini, sebagai berikut:

a. Harga

Harga adalah suatu nilai tukar yang bisa disamakan dengan uang atau barang lain untuk manfaat yang diperoleh dari suatu barang atau jasa bagi seseorang atau kelompok pada waktu tertentu dan tempat tertentu. Istilah harga digunakan untuk memberikan nilai finansial pada suatu produk barang atau jasa.

b. Memori

Memori adalah media penyimpanan data sementara pada komputer.

c. HardDisk

HardDisk adalah perangkat keras yang digunakan untuk menyimpan data pada computer. Semua data yang ada dalam computer baik itu dokumen, gambar, data system, OS, aplikasi akan tersimpan dalam perangkat ini.

d. Ukuran Layar

Ukuran Layar adalah jarak antara dua titik atau diagonal layar, dengan satuan inci. Resolusi layar adalah jumlah piksel yang terdapat pada layar. Semakin tinggi resolusi layar maka semakin jelas gambar yang dihasilkan.

\subsection{Struktur Hirarki}

Pada saat peneliti menggunakan prinsip-prinsip dasar metode AHP untuk menentukan hasil penelitian dan pembahasan. Prinsip dasarnya ini, termasuk pada dekomposisi, perbandingan, sintesis prioritas, dan konsistensi.

Dekomposisi adalah mendefinisikan keseluruhan masalah dan menguranginya. Masalah kecil tersebut digambarkan dalam bentuk struktur hirarki yang terbagi menjadi 3 bagian, yaitu : Tujuan, Standar, dan Alternatif. 4 kriteria yang dimanfaatkan dalam evaluasi ini adalah Harga, Memori, HardDisk, Ukuran Layar.

Harga sangatlah penting untuk memilih laptop, atau sebagai nilai tukar yang setara dengan uang atau komoditas dan mengetahui harga, orang akan memiliki pemahaman yang lebih baik tentang harga yang sudah dipasarkan. Ukuran layar adalah ukuran laptop, tergantung pada pilihannya. Pengguna memilih laptop dan tingkat permintaan konsumen.

Memori adalah ukuran memori laptop yang mempermudah pengguna untuk menyimpan dan mendownload file yang dibutuhkan. Kapasitas harddisk sangat penting untuk memilih laptop untuk institusi manapun atau diantara staff atau siswa membutuhkan disket yang besar untuk menyimpan suatu database.

Responden dipilih berdasarkan merk Laptop pengguna. Oleh karena itu, mahasiswa yang menggunakan buku catatan sebagai alat untuk memenuhi kebutuhan presentasi atau pun orang awam dipakai untuk bekerja. Responden dipilih secara tidak berurut dengan proporsi yang sama. 
INDONESIA JOURNAL INFORMATION SYSTEM (IDEALIS)

Volume 5, Nomor 1, Januari 2022

ISSN 2684-7280 (online)

Halaman 59-68

available online at http://jom.fti.budiluhur.ac.id/index.php/IDEALIS/index

Berdasarkan kriteria dan alternatif yang telah diambil, maka disusunlah dalam sebuah bentuk hirarki agar lebih mempermudah dalam pengolahan data. Kriteria dan Alternatif penilaian kerja dijelaskan pada gambar 2 yaitu gambar struktur hirarki:

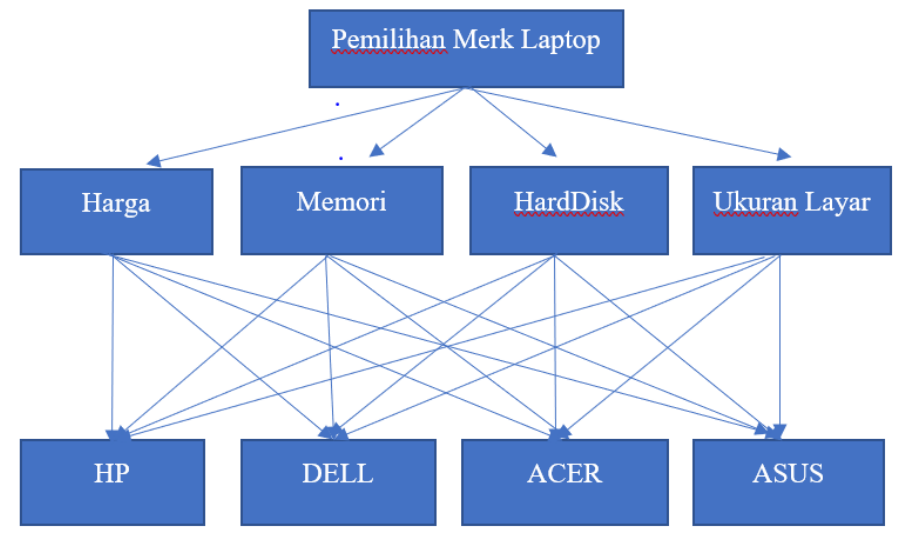

Gambar 2. Struktur Hirarki Pemilihan Merk Laptop dengan Metode AHP

Pada gambar 2, dapat dilihat bahwa main kriteria yang dibandingkan yaitu : Harga, Memori, HardDisk, Ukuran Layar. Perbandingan antar main kriteria dan alternatif ini dilakukan berdasarkan pemilihan harga, jenis dan ukuran yang tidak terlalu jauh berbeda, (lihat Tabel 2). Hirarki diatas, menggambarkan pemecahan masalah yang dibagi menjadi beberapa bagian, yaitu tujuan, kriteria dan alternatif.

Tabel 2. Tabel Kriteria

\begin{tabular}{lll}
\hline No & Kriteria & Penjelasan \\
\hline 1 & Harga & Menilai suatu harga perMerk \& tingkat kepuasan dalam pemilihan laptop \\
2 & Memori & Menilai tingkat penyimpanan pada laptop \\
3 & HardDisk & Menyimpan suatu data yang masukan dari suatu data input \\
4 & UkuranLayar & Menilai besar atau perinch laptop \\
\hline
\end{tabular}

\subsection{Model Hirarki Pemilihan Merk Laptop}

\subsubsection{Nilai Harga}

Bersumber pada standar harga akan ditentukan dari nilainya, terdiri dari 5 bilangan AHP, sebagaimana dijelaskan dalam Tabel 3:

Tabel 3. Bobot Harga

\begin{tabular}{lll}
\hline Harga & Bobot & Keterangan \\
\hline$<4-5,5 \mathrm{Jt}$ & 9 & Tidak Mahal \\
$5,5 \mathrm{Jt}-7 \mathrm{Jt}$ & 8 & Sedang \\
$7-8,5 \mathrm{Jt}$ & $5-7$ & Mahal \\
$8,5 \mathrm{Jt}-15 \mathrm{Jt}$ & $3-4$ & Cukup Mahal \\
$>15-23 \mathrm{Jt}$ & $1-2$ & Sangat Mahal \\
\hline
\end{tabular}

\subsubsection{Nilai Kapasitas Memori}

Bersumber pada kapasitas memori akan ditentukan nilainya, pada nilai ini terdiri dari 5 bilangan AHP, sebagaimana dijelaskan dalam Tabel 4:

Tabel 4. Bobot Memori

\begin{tabular}{lll}
\hline Kapasitas Memori & Bobot & Keterangan \\
\hline 16GB & 9 & Sangat Baik \\
8GB & 8 & Baik \\
4GB & $5-7$ & Cukup \\
2GB & $3-4$ & Kurang Baik \\
1GB & $1-2$ & Tidak Baik \\
\hline
\end{tabular}


INDONESIA JOURNAL INFORMATION SYSTEM (IDEALIS)

Volume 5, Nomor 1, Januari 2022

ISSN 2684-7280 (online)

Halaman 59-68

available online at http://jom.fti.budiluhur.ac.id/index.php/IDEALIS/index

\subsubsection{Nilai Kapasitas HardDisk}

Bersumber pada standart HDD akan ditentukan nilainya, pada nilainya terdiri dari 5 bilangan AHP, sebagaimana dijelaskan dalam Tabel 5:

Tabel 5. Bobot HardDisk

\begin{tabular}{lll}
\hline Kapasitas HDD & Bobot & Keterangan \\
\hline >640GB & 9 & Sangat Baik \\
640GB & 8 & Baik \\
500GB & $5-7$ & Cukup \\
320GB & $3-4$ & Kurang Baik \\
250GB & $1-2$ & Tidak Baik \\
\hline
\end{tabular}

\subsubsection{Nilai dari Ukuran Layar}

Bersumber pada standart Ukuran Layar akan ditentukan nilainya, pada nilainya terdiri dari 5 bilangan AHP, sebagaimana dijelaskan dalam Tabel 6 :

Tabel 6. Bobot Ukuran Layar

\begin{tabular}{lll}
\hline Kapasitas HDD & Bobot & Keterangan \\
\hline $14 ”$ & 9 & Sangat Baik \\
$10 ”$ & 8 & Baik \\
$13 ”$ & $5-7$ & Cukup \\
$12 ” / 11 ”$ & $3-4$ & Kurang Baik \\
$17 ” / 15 ”$ & $1-2$ & Tidak Baik \\
\hline
\end{tabular}

\subsection{Perbandingan}

Matriks perbandingan berpasangan diisi dengan angka untuk mempresentasikan kepentingan relatif elemen terhadap elemen lainnya. Proses ini dilakukan untuk membandingkan tiap elemen dari berbagai kriteria, subkriteria serta alternatife secara berpasangan. Angka-angka tersebut dimasukan kedalam matriks perbandingan berpasangan berdasarkan hasil data dari kuisioner. Jumlah kuisioner yang disebar untuk sampel penelitian ini sekitar 30 responden.

\subsection{Pengolahan Data Menggunakan AHP}

Dari hasil pengisian kuesioner yang telah disebarkan kepada responden, kemudian dibuat dalam bentuk matriks perbandingan berpasangan untuk mendapatkan bobot dari kriteria masing-masing. Untuk memudahkan dalam perhitungannya, maka dibuatlah dalam bentuk tabel dan setiap elemennya didesimalkan. Berdasarkan matriks perbandingan yang telah dibuat maka data-data tersebut dapat diolah untuk memperoleh indeks konsistensi dan rasio konsistensi. Dengan demikian hasil matriks berpasangan untuk masing-masing kriteria dan alternatif yang dibuat adalah dapat dilihat pada tabel-tabel berikut ini :

1. Kriteria Utama

Tabel 7. Vektor Eigen Kriteria Utama

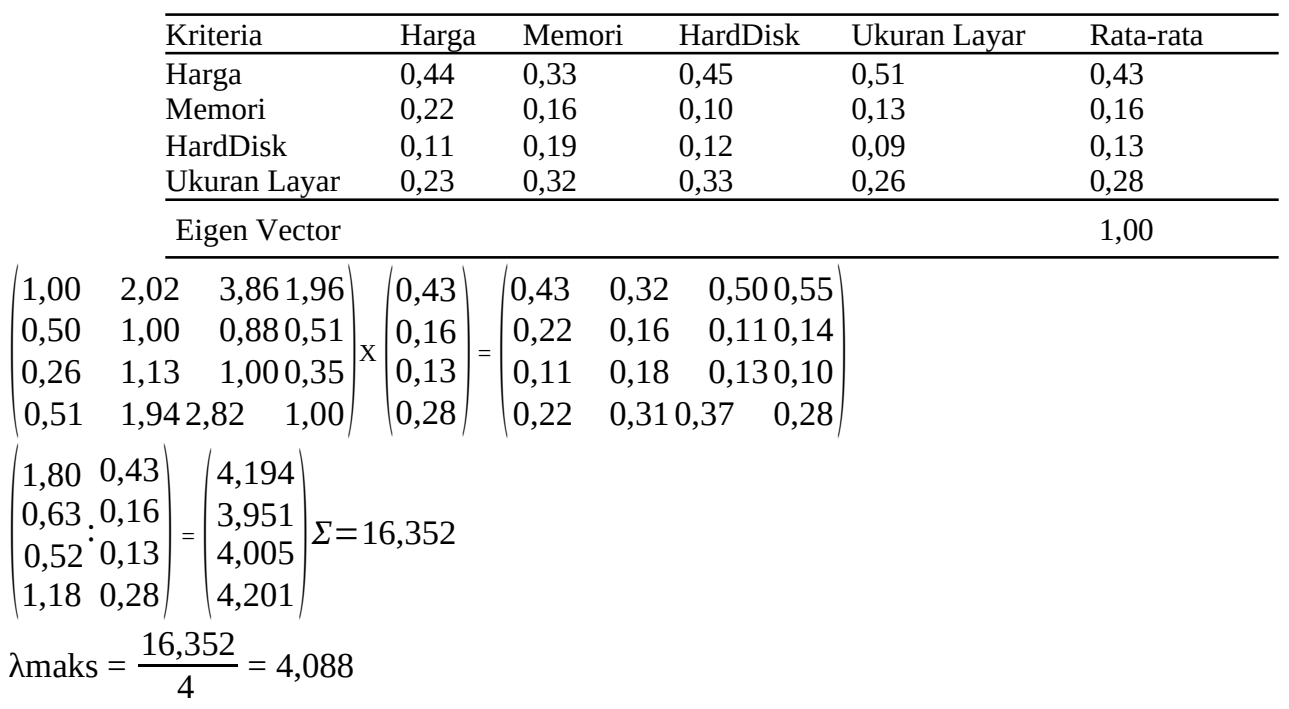


INDONESIA JOURNAL INFORMATION SYSTEM (IDEALIS)

Volume 5, Nomor 1, Januari 2022

ISSN 2684-7280 (online)

Halaman 59-68

available online at http://jom.fti.budiluhur.ac.id/index.php/IDEALIS/index

$$
\mathrm{CI}=\frac{(\lambda m a k s-n)}{(n-1)}=\frac{(4,088-4)}{(4-1)}=0,0293
$$

Untuk n=4, RI=0,9, maka:

$\mathrm{CR}=\frac{C I}{R I}=\frac{0,0293}{0,9}=0,0326$

Karena CR $<0,1$ berarti preferensi responden sesuai dengan hasil perhitungan pada tabel diatas, maka menunjukkan bahwa Harga adalah pilihan terpenting untuk minat laptop dengan nilai bobot 0,43 atau $43 \%$ berikutnya adalah Ukuran Layar dengan nilai bobot 0,28 atau 28\% selanjutnya Memori dengan nilai bobot 0,16 atau $16 \%$ dan terakhir HardDisk dengan nilai bobot 0,13 atau 13\%.

2. Alternatif Harga

Tabel 8. Vektor Eigen Alternatif Harga

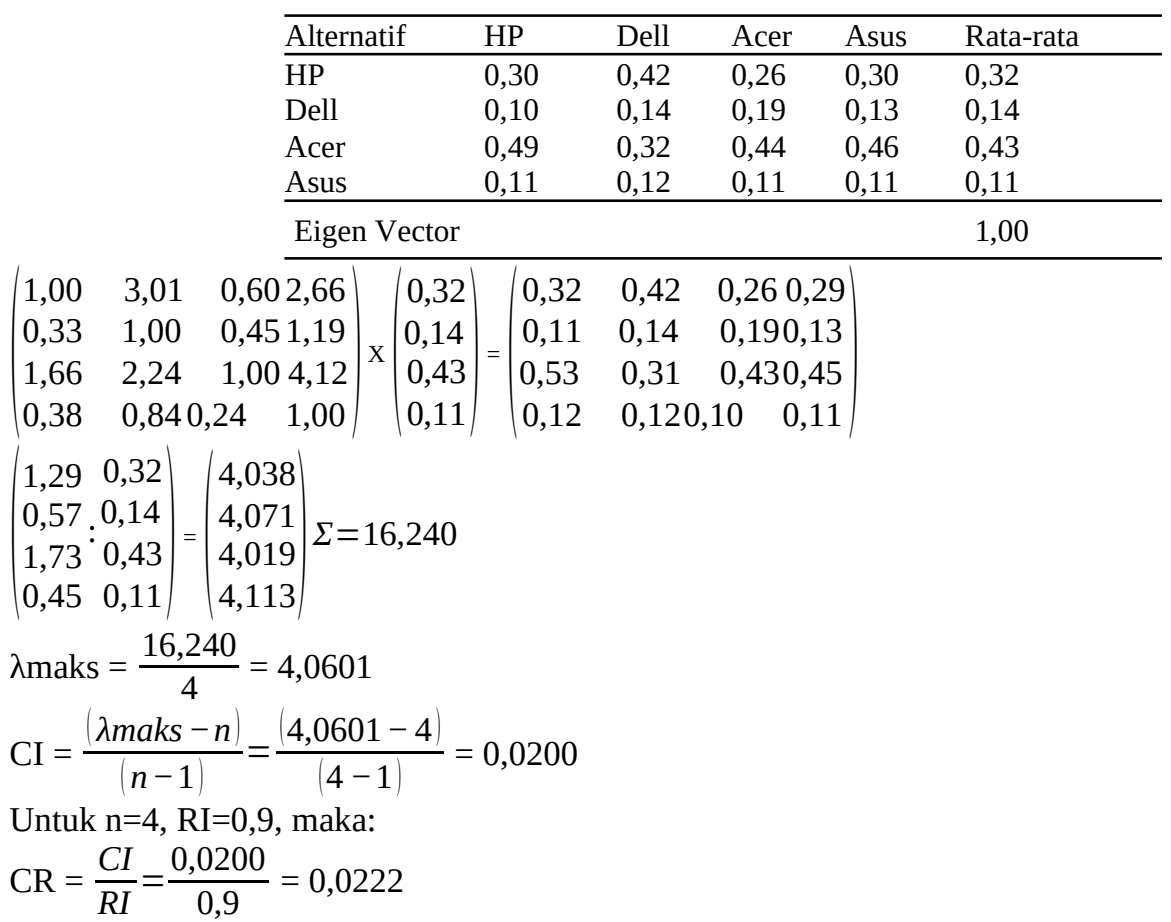

Karena CR $<0,1$ berarti preferensi responden sesuai dengan hasil perhitungan pada tabel diatas, maka menunjukkan bahwa Acer adalah pilihan terpenting alternatif Harga untuk minat laptop dengan nilai bobot 0,43 atau 43\% berikutnya adalah HP dengan nilai bobot 0,32 atau 32\% selanjutnya Dell dengan nilai bobot 0,14 atau $14 \%$ dan terakhir Asus dengan nilai bobot 0,11 atau 11\%.

3. Alternatif Memori

Tabel 9. Vektor Eigen Alternatif Memori

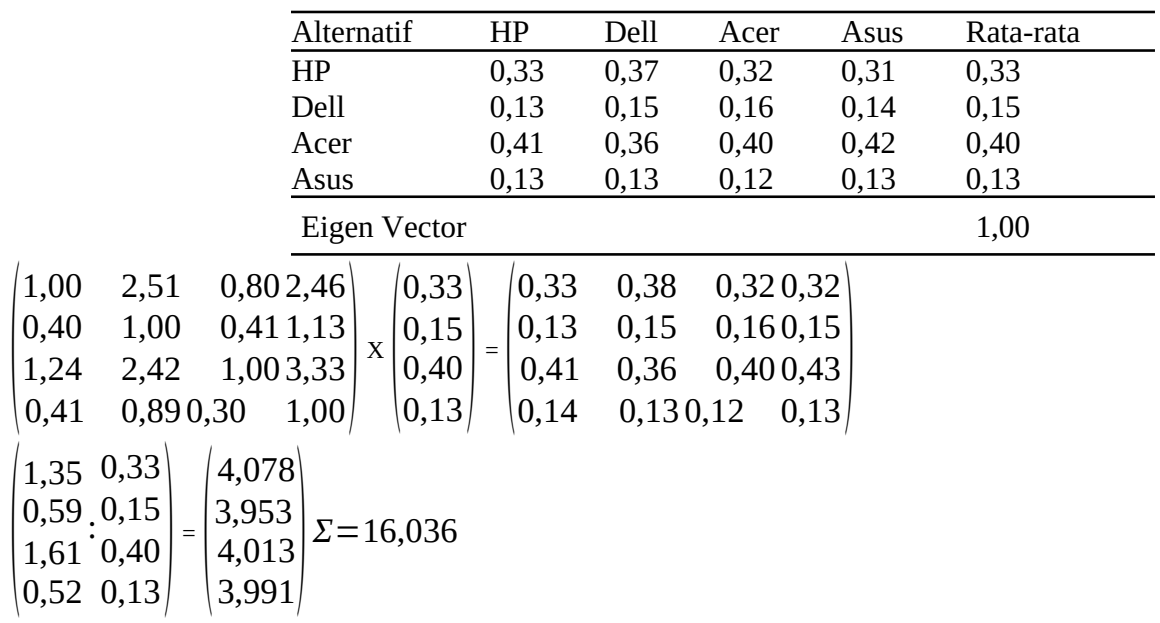


INDONESIA JOURNAL INFORMATION SYSTEM (IDEALIS)

Volume 5, Nomor 1, Januari 2022

ISSN 2684-7280 (online)

Halaman 59-68

available online at http://jom.fti.budiluhur.ac.id/index.php/IDEALIS/index

$$
\begin{aligned}
& \lambda \text { maks }=\frac{16,036}{4}=4,009 \\
& \mathrm{CI}=\frac{(\lambda \text { maks }-n)}{(n-1)}=\frac{(4,009-4)}{(4-1)}=0,003
\end{aligned}
$$

Untuk n=4, RI=0,9, maka:

$\mathrm{CR}=\frac{C I}{R I}=\frac{0,003}{0,9}=0,0033$

Karena CR $<0,1$ berarti preferensi responden sesuai dengan hasil perhitungan pada tabel diatas, maka menunjukkan bahwa Acer adalah pilihan terpenting alternatif Memori untuk minat laptop dengan nilai bobot 0,40 atau $40 \%$ berikutnya adalah HP dengan nilai bobot 0,33 atau 33\% selanjutnya Dell dengan nilai bobot 0,15 atau $15 \%$ dan terakhir Asus dengan nilai bobot 0,13 atau $13 \%$.

4. Alternatif HardDisk

Tabel 10. Vektor Eigen Alternatif Memori

\begin{tabular}{llllll}
\hline Alternatif & HP & Dell & Acer & Asus & Rata-rata \\
\hline HP & 0,30 & 0,41 & 0,29 & 0,29 & 0,32 \\
Dell & 0,07 & 0,10 & 0,12 & 0,10 & 0,10 \\
Acer & 0,48 & 0,38 & 0,47 & 0,48 & 0,45 \\
Asus & 0,14 & 0,12 & 0,12 & 0,12 & 0,12 \\
\hline \multicolumn{2}{l}{ Eigen Vector } & & & & 1,00 \\
\hline
\end{tabular}

$\left(\begin{array}{llll}1,00 & 4,11 & 0,63 & 2,41 \\ 0,24 & 1,00 & 0,26 & 0,86 \\ 1,60 & 3,85 & 1,00 & 4,01 \\ 0,46 & 1,17 & 0,25 & 1,00\end{array}\right) \times\left(\begin{array}{l}0,32 \\ 0,10 \\ 0,45 \\ 0,12\end{array}\right)=\left(\begin{array}{lll}0,32 & 0,41 & 0,280,29 \\ 0,08 & 0,10 & 0,120,10 \\ 0,51 & 0,39 & 0,450,48 \\ 0,15 & 0,120,11 & 0,12\end{array}\right)$

$\left(\begin{array}{ll}1,30 & 0,32 \\ 0,40 & 0,10 \\ 1,83 & 0,45 \\ 0,50 & 0,12\end{array}\right)=\left(\begin{array}{l}4,0741 \\ 3,9700 \\ 4,0627 \\ 4,1392\end{array}\right)$

$\Sigma=16,246$

$\lambda$ maks $=\frac{16,246}{4}=4,0615$

$\mathrm{CI}=\frac{(\lambda m a k s-n)}{(n-1)}=\frac{(4,0615-4)}{(4-1)}=0,0205$

Untuk n=4, RI=0,9, maka:

$\mathrm{CR}=\frac{C I}{R I}=\frac{0,0205}{0,9}=0,0228$

Karena CR $<0,1$ berarti preferensi responden sesuai dengan hasil perhitungan pada tabel diatas, maka menunjukkan bahwa Acer adalah pilihan terpenting alternatif HardDisk untuk minat laptop dengan nilai bobot 0,45 atau $45 \%$ berikutnya adalah HP dengan nilai bobot 0,32 atau 32\% selanjutnya Asus dengan nilai bobot 0,12 atau $12 \%$ dan terakhir Dell dengan nilai bobot 0,10 atau $10 \%$.

5. Alternatif Ukuran Layar

Tabel 11. Vektor Eigen Alternatif Ukuran Layar

\begin{tabular}{|c|c|c|c|c|c|c|c|}
\hline 1,00 & 2,79 & $1,773,00$ & & 0,42 & 0,42 & 0,45 & $0,550,30$ \\
\hline 0,3 & 1,00 & $0,491,80$ & & 0,16 & 0,15 & 0,16 & $0,150,18$ \\
\hline 0 & 2,05 & $1,003,62$ & $X$ & 0,31 & 0,24 & 0,33 & $0,310,36$ \\
\hline 3 & $0,560,2$ & 1,00 & & 0,10 & $0,1<$ & 0,090 & 0,10 \\
\hline
\end{tabular}

\begin{tabular}{llllll}
\hline Alternatif & HP & Dell & Acer & Asus & Rata-rata \\
\hline HP & 0,44 & 0,44 & 0,50 & 0,32 & 0,42 \\
Dell & 0,16 & 0,16 & 0,14 & 0,19 & 0,16 \\
Acer & 0,25 & 0,32 & 0,28 & 0,38 & 0,31 \\
Asus & 0,15 & 0,09 & 0,08 & 0,11 & 0,10 \\
\hline \multicolumn{2}{l}{ Eigen Vector } & & & & 1,00 \\
\hline
\end{tabular}


INDONESIA JOURNAL INFORMATION SYSTEM (IDEALIS)

Volume 5, Nomor 1, Januari 2022

ISSN 2684-7280 (online)

Halaman 59-68

available online at http://jom.fti.budiluhur.ac.id/index.php/IDEALIS/index

$$
\begin{aligned}
& \left(\begin{array}{ll}
1,72 & 0,42 \\
0,64 & 0,16 \\
1,24 & 0,31 \\
0,42 & 0,10
\end{array}\right)=\left(\begin{array}{l}
4,0836 \\
4,0194 \\
3,9981 \\
4,1500
\end{array}\right) \quad \Sigma=16,251 \\
& \lambda \text { maks }=\frac{16,251}{4}=4,0628 \\
& \mathrm{CI}=\frac{(\lambda m a k s-n)}{(n-1)}=\frac{(4,0628-4)}{(4-1)}=0,0209
\end{aligned}
$$

Untuk n=4, RI=0,9, maka:

$$
\mathrm{CR}=\frac{C I}{R I}=\frac{0,0209}{0,9}=0,0232
$$

\begin{tabular}{|c|c|c|c|c|c|c|c|}
\hline 320 & 0,330 & 0,320 0,420 & 0,430 & & 53 & 0,0420, & $0,350 \quad H P$ \\
\hline & 0,150 & $0,1000,160$ & 0,160 & 0,060 & 0,024 & $0,0130,045$ & 0,142 Dell \\
\hline & 0,400 & $0,4500,310$ & 0,1 & 5 & 0,064 & $0,0590,087$ & 0,39 \\
\hline & 0,130 & 0,100 & 0,280 & 0,047 & 0,0210 & 0,028 & 0,112 \\
\hline
\end{tabular}

Karena CR $<0,1$ berarti preferensi responden sesuai dengan hasil perhitungan pada tabel diatas, maka menunjukkan bahwa HP adalah pilihan terpenting alternatif Ukuran Layar untuk minat laptop dengan nilai bobot 0,42 atau 42\% berikutnya adalah Acer dengan nilai bobot 0,31 atau 31\% selanjutnya Dell dengan nilai bobot 0,16 atau $16 \%$ dan terakhir Asus dengan nilai bobot 0,10 atau $10 \%$.

\subsection{Hasil Perhitungan Akhir}

Setelah melakukan perhitungan data dari hasil pengisian kuesioner dan kemudian dijadikan matriks perbandingan, maka dari keseluruhan perhitungan tersebut memperoleh hasil sebagai berikut :

Tabel 12. Hasil Perhitungan Akhir

\begin{tabular}{lll}
\hline Merk Laptop & Hasil Akhir & Prosentase \\
\hline Acer & 394 & 0.4 \\
HP & 350 & 0.35 \\
Dell & 142 & 0.14 \\
Asus & 112 & 0.11 \\
\hline
\end{tabular}

Dari hasil perhitungan yang terlihat pada Tabel 12, laptop yang sangat popular dan diminati merupakan laptop acer dengan prosentase 40\%. Kemudian populer kedua merupakan Laptop HP dengan prosentase 35\%. Populer ketiga, Laptop Dell prosentase 14\%. Posisi terakhir adalah dari segi Ukuran Layar, mendapatkan prosentase $11 \%$. Berdasarkan hasil penelitian serta prosentase yang didapat, bisa disimpulkan bahwa laptop acer paling diminati dari berbagai merk laptop.

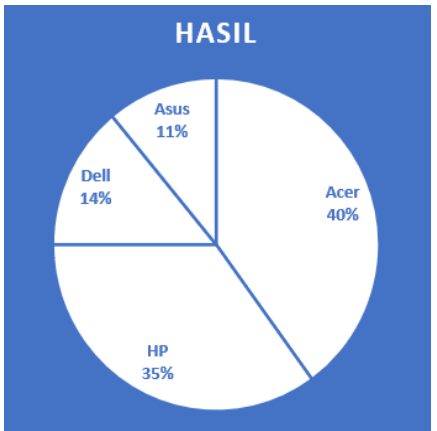

Gambar 3. Prosentase Hasil Perhitungan -Sumber: Peneliti (2021)

Pada bagian ini berisi analisis, hasil impelementasi ataupun pengujian serta pembahasan dari topik penelitian, yang bisa dibuat terlebih dahulu metodologi penelitian. Bagian ini juga merepresentasikan penjelasan yang berupa penjelasan, gambar, tabel dan lainnya.

\section{KESIMPULAN}

Peneliti menggunakan metode AHP (Analytical Hierarchy Proces) sebagai sistem penunjang keputusan pemilihan merek laptop pada mahasiswa, Sampel yang digunakan berasal dari mahasiswa. Berdasarkan hasil penelitian dari pengolahan data serta menganalisis data kuisioner yang didapat. Dilihat dari pengolahan data, 
INDONESIA JOURNAL INFORMATION SYSTEM (IDEALIS)

Volume 5, Nomor 1, Januari 2022

ISSN 2684-7280 (online)

Halaman 59-68

available online at http://jom.fti.budiluhur.ac.id/index.php/IDEALIS/index

peneliti menggunakan 4 Kriteria yaitu Harga, Memori, Hardisk serta ukuran layar dalam menentukan laptop merk mana yang terbaik dari merk laptop Acer, Asus, Dell dan HP. Setelah melewati serangkaian pengolahan data maka dapat disimpulkan Laptop acer paling banyak diminati dikalangan mahasiswa dan orang awam, berdasarkan prosentase dapat dilihat hasil dari penelitian tersebut ialah:

1. Merk Acer mempunyai bobot paling tinggi sekitar 40\%;

2. Merk Acer mempunyai bobot tertinggi kedua sekitar 35\%

3. Merk Dell mempunyai bobot prioritas ketiga sekitar $14 \%$

4. Merk HP mempunyai bobot paling rendah sekitar $11 \%$

\section{DAFTAR PUSTAKA}

[1] R. Su. Fahrezzy and A. F. M. Trenggana, "PENGARUH KUALITAS PRODUK DAN HARGA TERHADAP KEPUTUSAN PEMBELIAN KONSUMEN LAPTOP ASUS,” Jurnal Indonesia Membangun , vol. 17, no. 2, pp. 174183, 2018

[2] S. Sunarsa and I. H. Rani, "Sistem Pendukung Keputusan Pemilihan Laptop Untuk Karyawan Pada PT. Indotekno Dengan Menggunakan Metode Analitycal Hierarchy Process," Jurnal JITK, vol. 2, no. 1, pp. 5-10, 2016.

[3] M. N. S. Kastawi and S. Widodo, "Teknik Pengambilan Keputusan Dalam Menentukan Model Manajemen Pendidikan Menengah," Kelola Jurnal Menajemen Pendidikan, vol. 4, no. 2, 2017.

[4] V. B. Setyo Adi and E. Suryawardana, "Perilaku Konsumen Dalam Menggunakan Jasa Transportasi Ojek Online Di Semarang," Jurnal Ilmiah Solusi, vol. 16, no. 4, 2018.

[5] E. A. Riyanto and T. Haryanti, "SISTEM PENDUKUNG KEPUTUSAN PEMILIHAN TELLER POOLING TERBAIK PADA PT. BCA," Jurnal Pilar, vol. 13, no. 1, pp. 128-135, 2017.

[6] A. t. Priandika, "Model Penunjang Keputusan Penyeleksian Pemberian Beasiswa Bidikmisi Menggunakan Metode Analytical Hierarchy Process," Jurnal Teknoinfo, vol. 10, no. 2, 2016.

[7] M. Ridwan, M. F. Aponno and J. Pelupessy, "Perhitungan Dan Penyajian Laporan Penjualan Menggunakan Pivot Table Pada Ud. Multi Tehnik," Jurnal Maneksi, vol. 9, no. 1, 2020.

[8] frieyadie, “Analytical Hierarchy Process (AHP),” http://frieyadie.web.id/analytical-hierarchy-process-ahp/, Aug. 27, 2016.

[9] A. E. Munthafa and H. Mubarok, "Penerapan Metode Analytical Hierarchy Process dalam Sistem Pendukung Keputusan Penentuan Mahasiswa Berprestasi,” Jurnal Siliwangi, vol. 3, no. 2, 2017.

[10] G. P. Sanyoto, R. I. Handayani, and E. Widanengsih, "Sistem Pendukung Keputusan Pemilihan Laptop Untuk Kebutuhan Operasional Dengan Metode AHP (Studi Kasus: Direktorat Pembinaan Kursus Dan Pelatihan Kemdikbud),” Jurnal Pilar Nusa Mandiri, vol. 13, no. 2, 2017. 